\title{
11. SUMMARY, JAPAN TRENCH TRANSECT
}

\author{
Roland von Huene, U.S. Geological Survey, Menlo Park, California \\ Marcus Langseth, Lamont-Doherty Geological Observatory, Palisades, New York \\ Noriyuki Nasu, Ocean Research Institute, University of Tokyo, Tokyo, Japan \\ and \\ Hakuyu Okada, Geoscience Institute, Faculty of Science, Shizuoka University, Shizuoka, Japan
}

\section{INTRODUCTION}

The Japan Trench transect constitutes one of the first studies of a convergent margin using both multichannel seismic reflection and multihole deep sea drilling data. This volume contains the results of that study by the shipboard participants of Legs 56 and 57 and by their shore-based colleagues. A principal objective of this interdisciplinary study was to determine the evolution of the Japan convergent margin and the style of tectonism at the landward slope of the Japan Trench. On earlier legs of the Deep Sea Drilling Project (Legs 18, 19, and $31)$, the Glomar Challenger drilled where sedimentary melanges beneath the landward slopes of trenches had been inferred because seismic records showed few coherent reflections. However, on each of these legs, the drilling time allotted was sufficient for only a single hole and the complementary geophysical data consisted mainly of single- rather than the more powerful multichannel reflection records. Therefore the data in the present study are considerably more abundant than for most other studies of a particular convergent margin.

For this study, various Japanese agencies and institutions carried out a comprehensive predrilling program of geophysical surveying. They mapped the morphology of the seafloor, the shallow subsurface structure, the magnetic field, and gravity field off northern Honshu eastward from the shore to beyond the seaward slope of the Japan Trench (Honza, 1977, and this volume). Transects are normal to the trench axis, with $25-\mathrm{km}$ spacings, and in the main drilling area between $39^{\circ} 30^{\prime} \mathrm{N}$ and $40^{\circ} 30^{\prime} \mathrm{N}$ tracks are spaced $8 \mathrm{~km}$ apart.

Murauchi and Ludwig (this volume) and Nagumo and others (this volume) carried out intensive seismic refraction studies that defined the velocity structure of the crust off northern Honshu. Five 24-channel seismic reflection lines (Figure 1) were run by Japan Petroleum Exploration (JAPEX), three of them for the Japan National Oil Corporation (JNOC), prior to drilling and two for the Ocean Research Institute of Tokyo University (ORI) after the drilling (Nasu et al., this volume) (Figure 1). Four of the multichannel seismic lines were run between $39^{\circ} 45^{\prime} \mathrm{N}$ and $40^{\circ} 40^{\prime} \mathrm{N}$ perpendicular to the Japan Trench. The remaining JNOC multichannel line trends parallel to the trench along the axis of the fore-arc basin and connects the northern and southernmost perpendicular lines. Another transverse multichannel seismic line perpendicular to the trench at $39^{\circ} 40^{\prime} \mathrm{N}$, which had been run earlier by the Shell Exploration Company, was provided for use of the project (Beck et al., 1976). Potential drill sites were selected from study of the seismic records, and seven of these were drilled on Legs 56 and 57 during the three months Glomar Challenger was off northern Japan. Two sites sampled sediment from the fore-arc basin, one sampled from the trench upper slope, two from the trench lower slope, one on the trench midslope terrace, and one from the trench seaward slope. Although the depth of sampling at some sites was less than hoped for, the Challenger was able to sample each submerged morphotectonic element of a convergent ocean margin.

\section{GEOLOGIC SETTING}

The insular geologic framework of Hokkaido and northern Honshu is divided into five north-trending tectonic belts described from west to east and shown in Figure 2.

1) "Green Tuff" belt: This belt is developed on the Sea of Japan side of Honshu and southwestern Hokkaido as well as along the Okhotsk Sea coast of northeastern Hokkaido. The Green Tuff belt is made up of a thick complex of green altered acidic to intermediate volcanic rocks, mainly Miocene, and marine sediment.

2) Kitakami-Abukama belt: This belt consists chiefly of metamorphic and plutonic rocks, unmetamorphosed Paleozoic and Mesozoic geosynclinal strata, and nonmarine to neritic Paleogene deposits. The major geologic framework of the Abukuma-Kitakami belt was established by the Early Cretaceous and subsequent erosion exposed this belt during the Cenozoic uplift.

In the Kitakami-Abukama belt on the Oshima Peninsula of southerwestern Hokkaido, a geosynclinal sequence of Carboniferous to Triassic rock underlies the Green Tuff pyroclastic deposits. Small landmasses composed mainly of Early Cretaceous or older pyroclastic rocks lie along the eastern margin of the belt. Among them, the Neocomian Rebun Group on Rebun Island correlates with similar strata exposed along the Pacific coast of the Kitakami Massif. Another is the Kabato landmass, made up of basic to intermediate volcanic rocks, chert, and clastic rocks of the Early Cretaceous age.

3) Ishikari belt: This belt is characterized by very thick Tertiary and Quaternary strata unconformably overlying Cretaceous geosynclinal sediment (Yezo Geosyncline; see Okada, 1974). The Eocene to Oligocene sequence (about $3000 \mathrm{~m}$ thick) consists of coal-bearing 


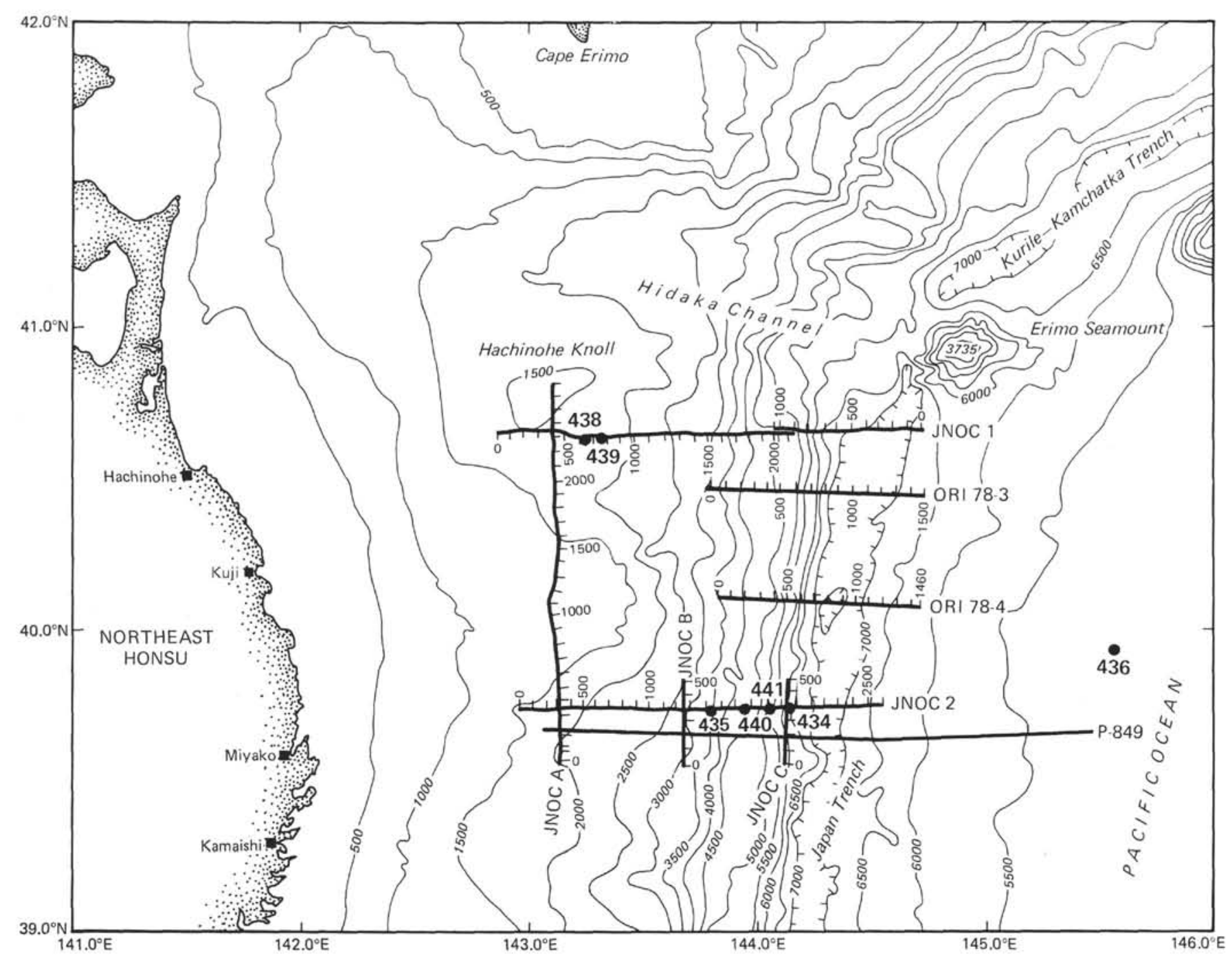

Figure 1. Map of northeastern Japan showing location of multichannel seismic lines and IPOD drill sites. P-849 was made by Shell International Petroleum Co. (Beck et al., 1976), Lines 1, 2, A, B, C, by JNOC; Lines 78-3 and 78-4 by the Ocean Research Institute, University of Tokyo (Nasu et al., this volume). Shotpoint numbers are shown along each line, contours at 500-meter intervals.

nonmarine rock in the lower part and marine strata in the upper part. Neogene sediment nearly $10 \mathrm{~km}$ thick rests unconformably on either Paleogene or Cretaceous strata. The Neogene sequence consists mostly of marine deposits, which have distinctive structures and composition such as chaotic deposits (Okada, in press) and serpentine sandstone (Okada, 1974). These sediments were deposited during the Hidaka Orogeny (Nagao, 1938), which culminated between the end of the Paleogene and the middle Miocene (Hunahashi, 1957).

The Ishikari belt extends southward beyond the coast to the Hidaka Trough and the Neogene Ishikari-Hidaka basin between Hokkaido and Honshu (Ishiwada and Ogawa, 1976), which contains Neogene sediment 8000 meters thick in places (Figure 2).

4) Kamuikotan-Hidaka-Tokoro belt: The western part of this belt contains the Kamuikotan metamorphic belt, which is characterized by high-pressure metamorphic rocks, ultramafic rocks, and phyllite. The little- metamorphosed Sorachi Group (Late Permian to Early Cretaceous) and unmetamorphosed Yezo Group (Early to Late Cretaceous) are also exposed in a narrow part of this belt.

The central part of the belt is occupied by the Hidaka metamorphic belt to the west and the Hidaka supergroup to the east. The former is composed of hightemperature metamorphic and plutonic rocks, which are thought to be equivalent to the Sorachi Group. The eastern part, specifically the Tokoro belt, consists of unmetamorphosed or weakly metamorphosed pre-Cretaceous eugeosynclinal rocks containing a considerable amount of submarine mafic volcanic rock.

5) Nemuro belt: This easternmost belt consists of a thick marine sequence of Campanian to Paleocene age. It contains more than 3000 meters of east-striking clastic deposits and pillow lava.

Knowledge of offshore geology is based primarily on geophysical data. A transect from the coast of northern 

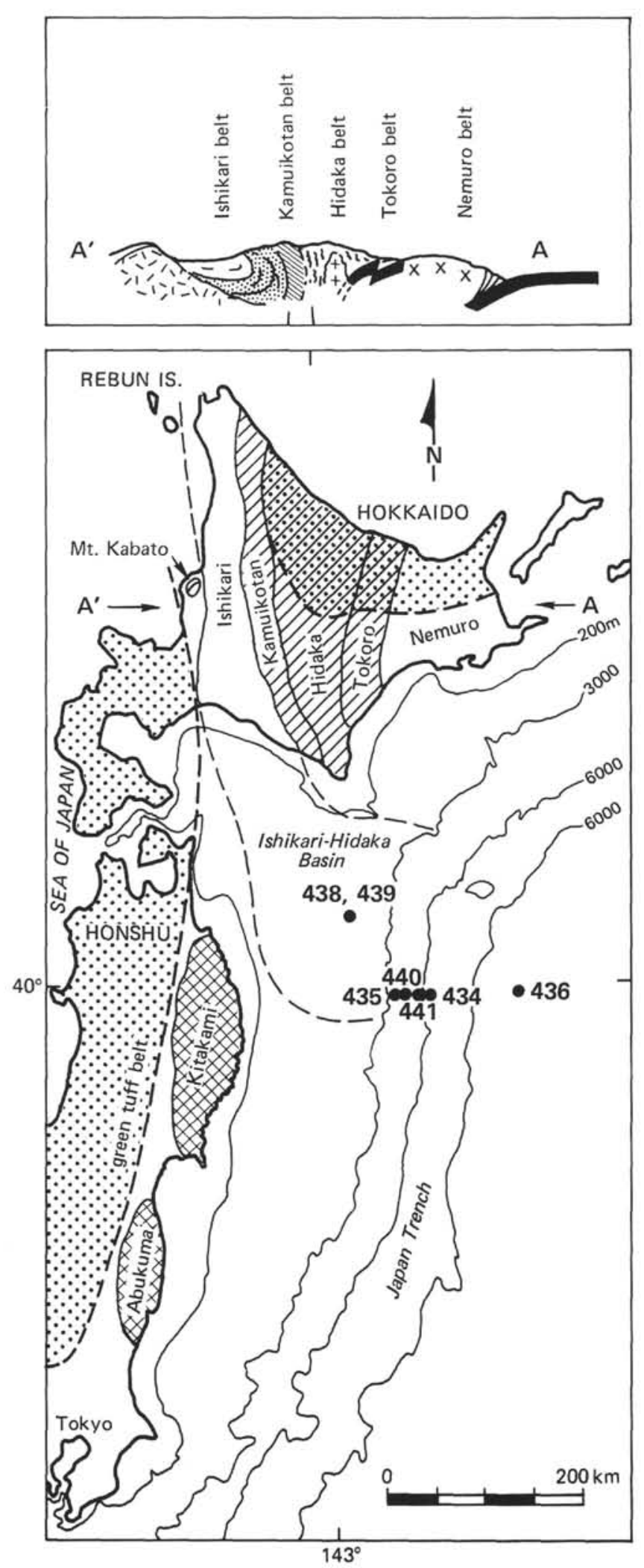

Figure 2. Generalized tectonic map of northern Japan showing major onshore belts. Diagrammatic section along $A A^{\prime}$ extends from northwestern Hokkaido across the island and continental margin in a southeast direction. Green Tuff belt is indicated by dotted pattern, Abakuma-Kitakami by crosshatch, and Kamuikotan-Hidaka by diagonal pattern.
Honshu, across the Japan Trench, and into the deep Pacific basin includes all the morphotetonic elements commonly found across convergent margins. Just off the coast is a shallow continental shelf generally $20 \mathrm{~km}$ wide and ranging from 5 to $40 \mathrm{~km}$. Continental slope is situated beyond this shelf, and further beyond, there is a deeper shelflike feature that contains the IshikariHidaka fore-arc basin. Because it is deeper than $1 \mathrm{~km}$, it has been called a deep sea terrace (Nasu, 1964). The deep sea terrace is $200 \mathrm{~km}$ wide, dips less than $1^{\circ}$ toward the Japan Trench, and contains a basin more than 150 $\mathrm{km}$ wide. It overlies thick crust with a continental velocity structure. Hence it has the geology of a continental shelf but is anomalously deep.

Just beyond the deep sea terrace is the Japan Trench landward slope, defined by dips generally between $3^{\circ}$ and $4^{\circ}$. This trench slope (Figure 3 ) is divided into an upper and lower part by a narrow but long midslope terrace (Honza, this volume) which corresponds in position to the transition from continental to intermediate crustal velocity structure (Murauchi and Ludwig, this volume; Nagumo and others, this volume). It should be noted that unlike some other island arcs, where continental crust has been reported to extend only to the shelf edge, the continental crust here extends beyond the deep sea terrace and well down the Japan Trench upper slope.

From the midslope terrace to the floor of the trench, the lower slope has an average inclination from $4^{\circ}$ to $7^{\circ}$, and locally the slope is probably steeper. The refraction results show sediment beneath the lower slope that is about 5 to $7 \mathrm{~km}$ thick near the midslope terrace. The lower slope sediment is underlain by the ocean crust (Ludwig et al., 1966), which is also indicated by magnetic anomalies (Honza, this volume).

The trench floor is check-shaped $(\nu)$ in profile, and only a small amount of sediment is ponded in it. From the trench floor at typical depths of 7300 meters, the seafloor slopes gently upward to the east to form a

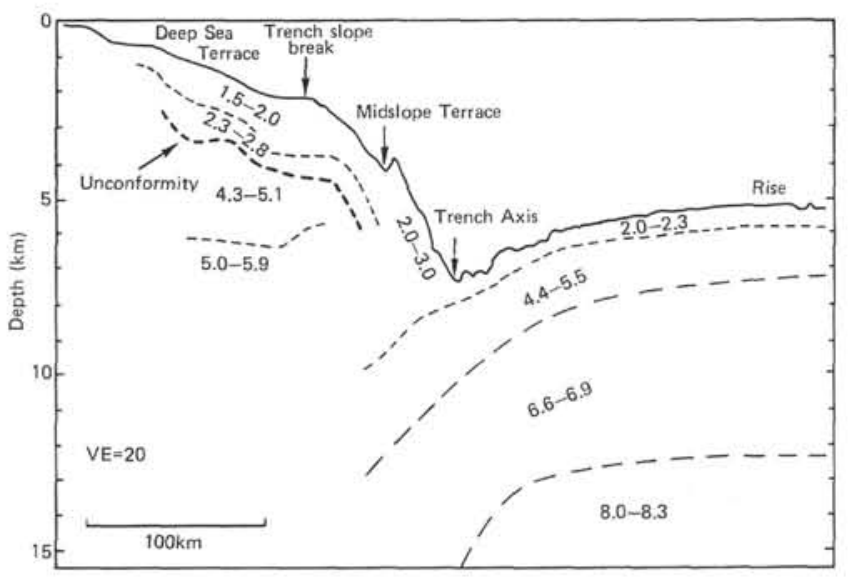

Figure 3. Velocity structure across the Japan Trench transect (modified from Murauchi and Ludwig, this volume). The ranges of compressional wave velocity in $\mathrm{km} / \mathrm{s}$ are shown in layers that can be correlated between 12 refraction stations located along JNOC multichannel seismic reflection Record 2. 
broad rise, like those characteristically found elsewhere seaward of active deep sea trenches. The oceanic crust on the rise is broken by numerous faults that form a distinctive horst-and-graben topography (Ludwig and others, 1966; Honza, this volume). A uniform sedimentary layer 500 to 600 meters thick, conforming to the topography, lies on top of the igneous oceanic crust.

\section{INTERPRETATION OF SEISMIC RECORDS}

The two multichannel records used to select the sites were interpreted using the constraints provided by the drill core data, predrilling geophysical surveys, and by the two postdrilling multichannel records (Figure 4). Although continental crust seems to end abruptly at the midslope terrace-an inference supported by the refraction data as well-details of the juncture are not well resolved in any seismic record, probably because of its complex structure. In reflection records, older sediment on the continental crust is in turn overlain unconformably by an orderly sequence of beds that not only fill the fore-arc basin but also extend down the trench upper slope to the midslope terrace. The unconformity has regional extent. The records of the area between the midslope terrace and the trench are largely obscured by diffractions. The sediment contains faint dipping reflections and is underlain by a strong reflection from the top of the igneous oceanic crust. This ocean crust reflection can be followed from the deep Pacific basin beneath the trench, beneath the trench lower slope, and in some instances, beneath the trench upper slope as well. The seaward end of the continental crust appears to be bowed down toward the trench, because the angular unconformity, an ancient subaerial erosion surface, is arched and depressed $3 \mathrm{~km}$ deeper at the midslope terrace than beneath the deep sea terrace (Figure 4). This downbowing may explain the series of steep normal and reverse faults beneath the deep sea terrace and the trench upper slope, but none of the displacements seem significantly to affect deep sedimentary horizons. The vertical fault displacement at depths greater than $1 \mathrm{~km}$ is less than can be resolved by seismic methods. On the trench upper slope, large-scale slumps or other forms of gravitational failure are suggested by back rotation of beds and displacement of equivalent age horizons between drill holes; however, the seismic resolution of structure is insufficient to establish the slip planes bounding any of the blocks with much confidence. Other evidence of slumping is the termination of beds at the seafloor along slump scars that are easily $5 \mathrm{~km}$ across (Figure 4).

Near its juncture with the Kurile Trench, the Japan Trench appears to be filled with a large accumulation of material derived from downslope mass movement. This material has the form of a toe projecting from the slope into the trench with a rough but level upper surface (JNOC Record 1, Figure 4). In contrast, the possible zone of subduction-accreted material beneath the lower slope is best seen in JNOC Record 2, where the toe is absent (Figure 4). This undrilled zone on the basis of seismic data which show landward-dipping reflections is inferred to consist of sediment scraped off the ocean crust. The inferred accreted material is covered by seaward-dipping horizons from which slope deposits were recovered by drilling.

\section{STRATIGRAPHY OF DRILL HOLES}

Most of the sediment recovered by drilling on the Japan Trench transect is hemipelagic silty claystone, rich in diatoms and volcanic ash. The claystone is typical of the sediment commonly deposited in a continental slope environment, and even the upper part of the section seaward from the trench is largely from terrigenous sources. There are biostratigraphic datums of high- and low-latitude zonations (Figure 5) because the transect is in the mixing area of the cold Oyashio and warm Kuroshio currents. During the Neogene, fluctuations in these currents resulted in the deposition of warm-water, temperate, and cold-water microfossil successions. The temporal resolution afforded by the microfossil assemblages is excellent, and the microfossil datums and paleoclimatic events have been tied to paleomagnetic stratigraphy and to the absolute time scale.

At Sites 438 and 439 the complete Neogene and the latest Paleogene section was penetrated (Figures 4 and 5). At these sites near the top of the trench landward slope and on thick crust with a continental velocity structure, a landward reference section was cored. The Pleistocene to lower Miocene section of terrigenous diatomaceous claystone overlies lower Miocene interbedded siltstone and turbidites, which in turn cover a massive Oligocene sandstone containing numerous articulated megafossils; below is a 48-meter breccia-conglomerate unit of dacitic boulders. The transition from Cretaceous to Tertiary rock is at the marked angular unconformity (Figure 4). This marked unconformity was cut across a steeply dipping silicified claystone of Late Cretaceous age that was a source of clasts and lithic fragments for the Oligocene and lower Miocene units.

At Site 435 on the trench upper slope, a 245 -meter section of Pliocene to Pleistocene hemipelagic diatomaceous silty claystone was recovered. Volcanic ash is interbedded in thin layers and is also dispersed throughout the claystone, as was commonly observed at the other sites. At Site 440 the same mudstone was recovered except that the Pleistocene section is much thicker, owing to ponding along the midslope terrace. A large part of the section below 400 meters is a recemented tectonic microbreccia that fragmented in place after the claystone had been lithified. This brecciation appears to occur along closely spaced fractures and veins that may initially have been dewatering conduits. Well-defined slump structures were seen in the cores from this site.

Sites 441 and 434 on the trench lower slope were drilled to 680 and 638 meters respectively, yet none of the sediment recovered was a deep ocean brown clay, biogenic ooze, or chert. At both sites most of the Pleistocene section is missing and is presumed to have been lost by slumping. The cores from below about 140 meters are mainly drill cuttings composed of rock chips measuring less than $1 \mathrm{~cm}$, and the few coherent pieces of core crumble into such chips readily. The sections of 

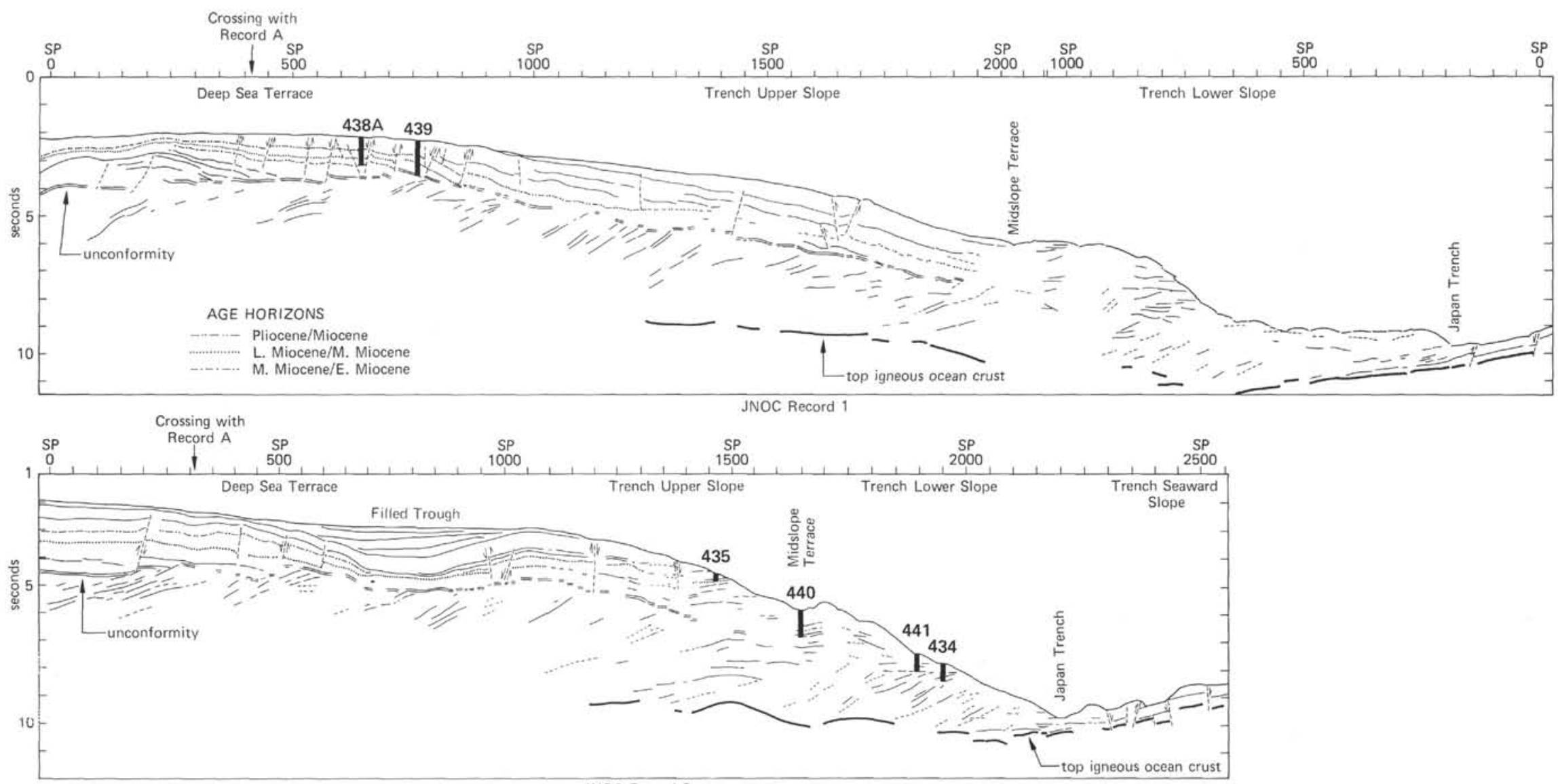

$\operatorname{NOC}$ Record 2

Figure 4. Tracings of selected reflections in JNOC Records 1 and 2 and interpretation of faults. The location of IPOD drill sites are indicated by site numbers. Seismic horizons corresponding with Pliocene/Miocene, upper/middle Miocene, and middle/lower Miocene age boundaries as determined at Sites 438 and 439 are indicated with coded lines. The age horizons were projected to Record 2 from Sites 438 and 439 by tracing them on JNOC Record A (see Figure 1). The age boundaries are made with shorter dashes where uncertain because of loss of reflection continuity; dashed reflections indicate very weak amplitudes and possible confusion with diffractions. Faults are indicated by dashed lines where the data requires them and are drawn vertical where they dip steeply in an unknown direction. Each shotpoint interval on the horizontal scale is 50 meters. 


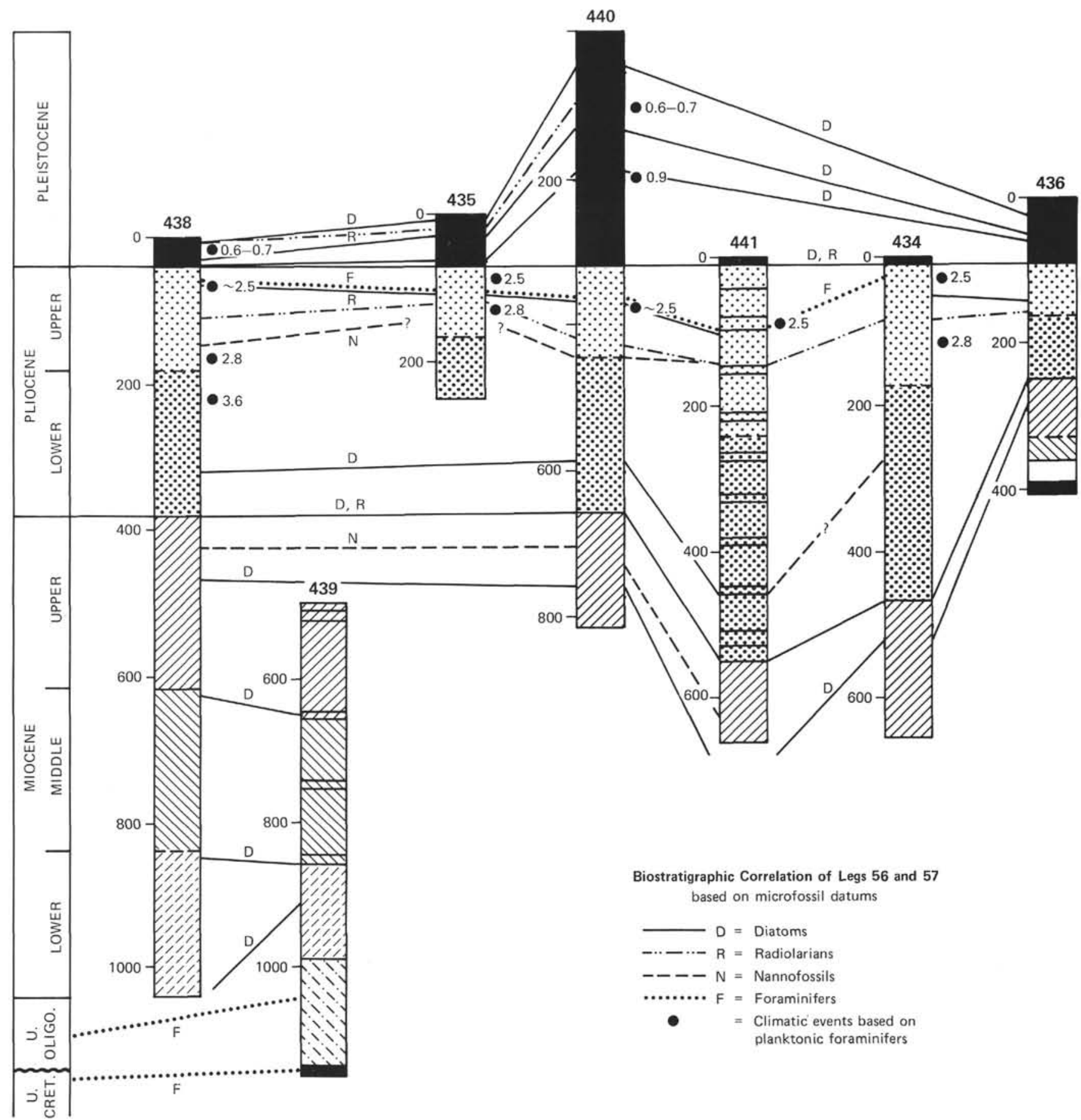

Figure 5. Summary of biostratigraphy along the Japan Trench transect and correlation of datums between cores. Assigned ages are indicated in the illustration by patterns.

core recovered intact are cut by many microfractures. They consist in places of a resedimented breccia of mudstone chips in a mudstone matix, and in one core the mudstone chips are squeezed together with little intervening matrix.

At Site 436, $20 \mathrm{~km}$ seaward from the Japan Trench on the outer broad rise, the 360 -meter thick middle Miocene to Pleistocene section consists of hemipelagic diatomaceous mudstone with various amounts of dia- toms and volcanic ash. The middle Miocene to Cretaceous section consists of 20 meters of brown clay and below is chert of Cretaceous age. According to seismic data the Cretaceous section is about 160 meters thick.

\section{SEDIMENTATION}

Neogene sediment recovered from the drill holes is mostly clay and silt with varying amounts of volcanic ash and diatoms. Clay is generally 50 to 60 per cent of 
the sample. Ash occurs in thin layers and is also mixed into the mud by physical and biogenic reworking. The concentration of diatoms depends largely on the rate of terrigenous sedimentation, and in places where rates were low, they are present in sufficient quantity to form oozes. Generally, however, diatoms constitute 25 to 30 per cent of the fore-arc and deep ocean basin sediment and 10 per cent of the trench lower slope sediment. Ash occurs in concentrations of 5 per cent to 10 per cent. Less common constituents are erratic pebbles and sand in Pliocene and Pleistocene sediment and secondary fine-grained carbonate minerals associated with porous ash layers below 600 meters. All considered, the sediment grain size and composition are surprisingly uniform in the samples from shelf to trench to deep ocean basin depositional environments. In fact, even sediment from the trench floor sampled by piston coring (Inouchi et al., 1976) is lithologically similar to that sampled by DSDP drilling.

The compositional uniformity seems consistent with accumulation rates when measured by simply plotting age against time (Figure 6). From the late Miocene to the present, most of the age-time plots have a constant slope with the exception of Site 436, where low rates of sedimentation are to be expected. When the effect of compaction is considered in our calculations, the rates at Site $\mathbf{4 3 6}$ in the Pacific basin are half those in the forearc basin and on the trench lower slope, rates are sometimes 3 to nearly 10 times greater than those in the forearc basin. The terrigenous fraction and volcanic ash accumulation rates increase, but the biogenic component rates stay essentially constant (Arthur et al., this volume).

The observed distribution of sediment along the Japan Trench transect requires bypassing of the fore-arc (Ishikari-Hidaka) basin because the source of most of the sediment is the Japanese Islands. This suggests that the sediment is transported in channels tranverse to the slope; however, in the areas where the morphology changes rapidly in response to rapid tectonism, channels and basins may be destroyed.

For instance, a broad trough in the fore-arc basin can be traced perhaps $200 \mathrm{~km}$ north toward its source area (Figure 7). The sediment filling the trough records Pliocene and Pleistocene uplift near the top of the trench slope (Nasu et al. and Arthur et al., this volume), an uplift that probably caused rearrangement of sediment pathways. The trough discharged at the top of the trench slope; the head of the trough is presently cut off by a modern channel, the Hidaka Channel. Hidaka Channel crosses the fore-arc (Ishikari-Hidaka) basin transverse to the regional trend and runs down the juncture of the Japan and Kurile trenches.

Neither the geophysical nor sample information is sufficient to make a comprehensive analysis of sediment pathways and loci of deposition; however, sediment pathways can be inferred from the features observed. As the filled trough suggests, channels parallel to the regional trend carry material along the fore-arc basins of the shelf and deep sea terrace. These channels commonly form behind low tectonic ridges paralleling the re- gional structural trend and are thus subject to disruption by local tectonism. For instance, the broad filled trough in JNOC Record 2, the bottom of which served as a trough pathway from the upper Miocene to upper Pliocene, was disrupted during uplift of the margin and then was filled (Figure 4). It may have been a major distributary for sediment from southwestern Hokkaido to the trench slope. In contrast, transverse channels, such as the Hidaka Channel, cut across the margin and bypass the Ishikari-Hidaka basin, transporting sediment from source areas directly to slope basins and to the trench. Such channels must discharge into the present midslope terrace basin, because the rate of accumulation of Pleistocene terrigenous material observed there is greater there (Site 440) than anywhere else on the margin. In addition, the presence of slump scars on the trench upper slope suggests that mass movement may have brought material down the slope to the terrace.

During the development of the present midslope basin, the adjacent trench lower slope may have steepened considerably, because sediment accumulated at a relatively high rate in Pliocene and Miocene time; present slopes are steep and Pleistocene seidment accumulated slowly if at all. This area must have served as a locus of rapid accumulation for initially deposited detritus from terrigeneous sources as well as slumps and other products of downslope sediment mass movement. Because the greater part of the Pleistocene section on the trench lower slope at Sites 434 and 441 is missing and slump scars are inferred from seismic records (Figure 4), we may hypothesize that oversteepening of this area during the Pliocene resulted in massive slope failure.

The uniformity of grain size and sediment composition can be explained by channelization of sediment near the coast, transport both transversely and laterally along the margin, and distribution to successive basins until sediment finally reached the trench. Transport appears to continue seaward some hundreds of kilometers beyond the trench to the deep Pacific basin, perhaps in nepheloid layers, where thick hemipelagic deposits are found (Arthur et al., this volume). Channelization near the coast is one explanation for the predominance of fine-grained clastic sediment. Channelization would concentrate relatively coarse-grained material in channel floors and fine-grained material in the interchannel areas. Because Sites 438 and 439 were drilled on a persistent structural high, the section sampled was probably biased toward the fine-grained fraction. On the other hand, the ponded section at Site 440 contains a coarser Pleistocene sequence, which may have been more representative of the coarser grain-size fraction during that period. In this context it is noteworthy that 5 per cent or less of the sediment recovered from the trench by piston coring is coarser than silt size.

Since the position of channels and basins is to a large degree controlled by tectonism, there may be tectonic significance in the multiplicity of events in the late Miocene and Pliocene, such as the increase in explosive volcanism (Cadet and Fujioka, this volume), uplift and abandonment of a channel in the fore-arc basin, the up- 

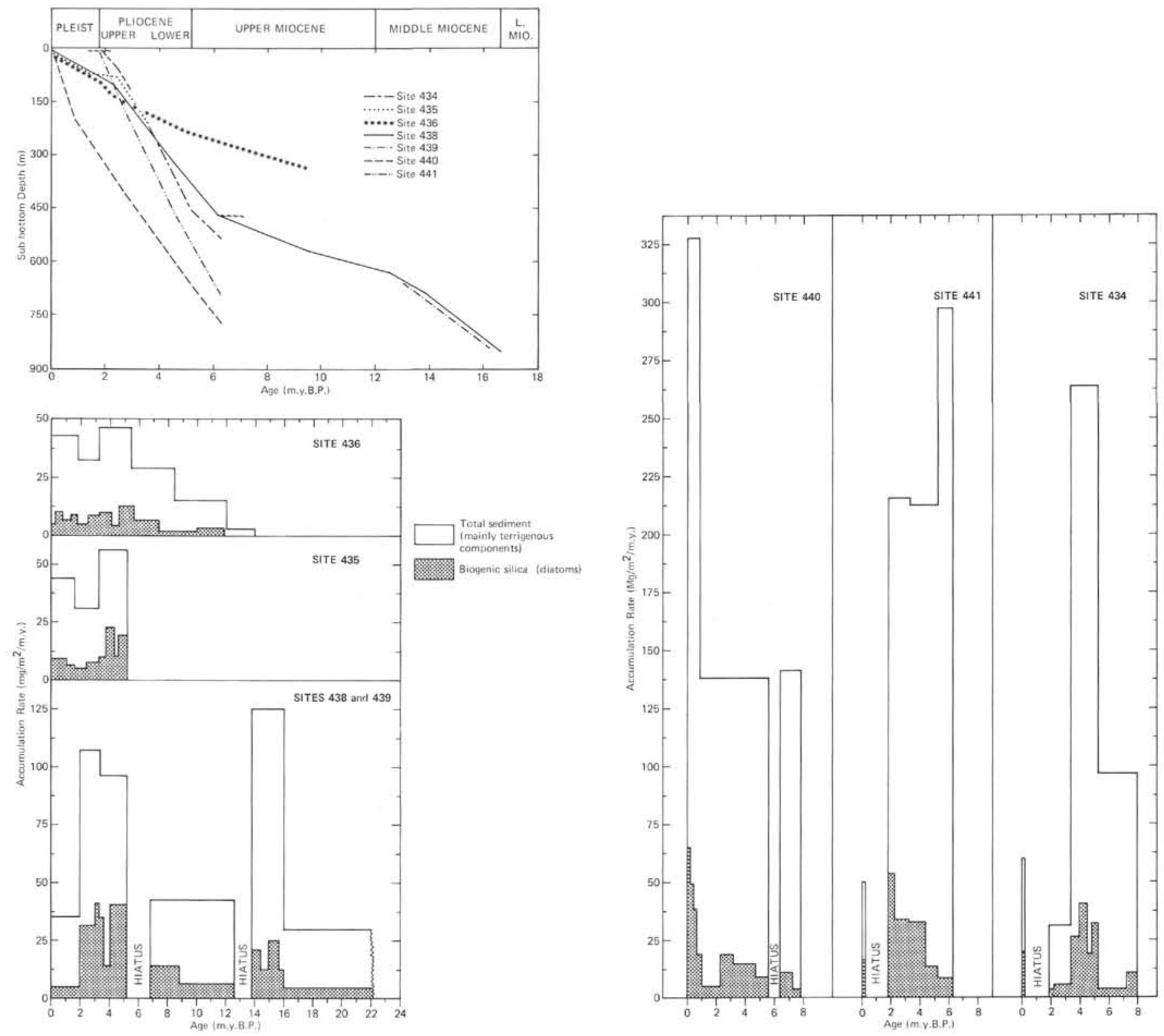

Figure 6. Accumulation rate of terrigenous and biogenic material with time.

lift of the deep sea terrace, development of the midslope terrace, destruction of a basin on the trench lower slope, and massive slumping-perhaps in response to oversteepening of the slope. This association of events is discussed further in the following sections.

\section{GEOTHERMAL OBSERVATIONS ON THE JAPAN TRENCH TRANSECT}

A number of observations made on Legs 56 and 57 provide information on the subseafloor temperature structure, both past and present. Among them are the high-resolution temperature logs made at Holes 438A, 439 , and $440 \mathrm{~B}$ and the maximum thermometer readings made at the bottom of Holes 438A and 439 (site chapters for Sites 438 and 439 , this volume, Pt. 1).

Gradients of 32 and $36^{\circ} \mathrm{C} / \mathrm{km}$ were determined in Holes $438 \mathrm{~A}$ and 439 , respectively. At Hole 440 a gradi- ent of $24^{\circ} \mathrm{C} / \mathrm{km}$ was determined. These values are believed to be representative of undisturbed conditions, once corrections are made for the circulation of seawater in the borehole during drilling. The vertical thermal conductance of the sedimentary sections over which the measurements were made has been well determined by hundreds of thermal conductivity measurements during Legs 56 and 57 . The conductance combined with the gradients show heat flows of 28 and $32 \mathrm{~mW} / \mathrm{m}^{2}$ at Sites 438 and 439 and $22.5 \mathrm{~mW} / \mathrm{m}^{2}$ at Site 440 .

These values indicate that present temperatures below these sites are anomalously low compared to typical ocean basin values. Extrapolation of the heat flow at Sites 438 and 439 indicates a temperature of 250 to $300^{\circ} \mathrm{C}$ at the top of the lithosphere which is 15 to $20 \mathrm{~km}$ below the site (Murauchi and Ludwig, this volume). At Site 440 , temperatures at this interface ( $5 \mathrm{~km}$ sub-bottom) 

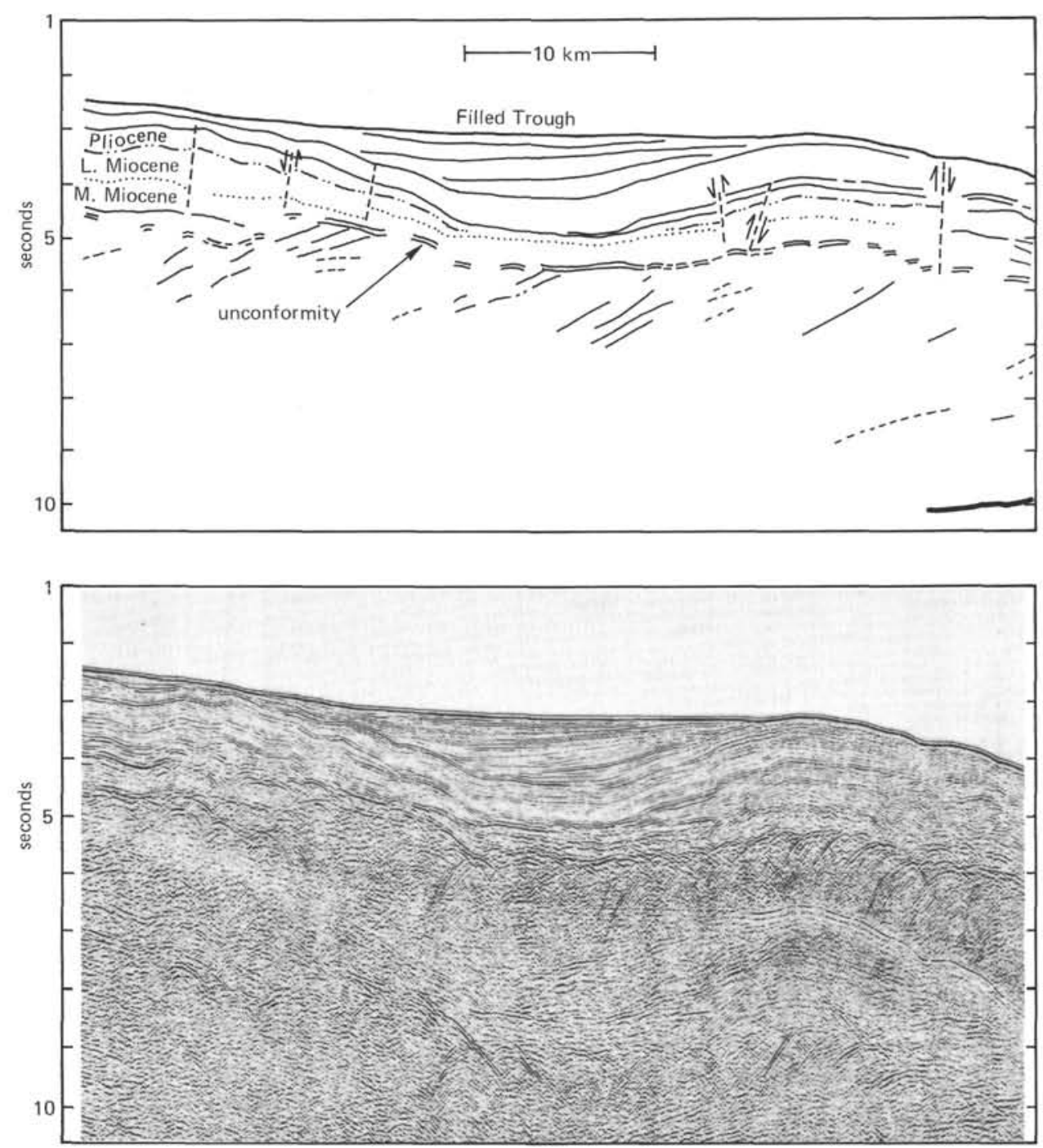

Figure 7. Section across a filled trough in the Ishikari-Hidaka fore-arc basin. Note that the apparent depocenters (not corrected for velocity and compaction) in the channel (1-3) shift landward, whereas Neogene depocenters of the basin (4 and 5) shift seaward. The seismic section is from JNOC Record 2, and the line drawing is a simplified tracing of reflections in the record. Age horizons have been followed from Sites 438 and 439 (see Figure 4).

may be less than $100^{\circ} \mathrm{C}$. Low temperatures and heat flows are to be expected at the edge of a margin actively underthrust by cold oceanic lithosphere (see, for example, models of Minear and Toksöz, 1970; Oxburgh and Turcotte, 1970).

\section{VOLCANIC ROCK IN THE FORE-ARC AREA}

One explanation for the boulder conglomerate of acidic to intermediate volcanic rocks recovered at Site 439 is that in Oligocene time the continental framework extended farther east than the present midslope terrace. The clasts have crystallization ages of 22 to 24 m.y. B.P. (Moore and Fujioka and Yanagisawa, this volume), range in size up to 1 meter across in the drill core, and are nearly monolithologic, all of which indicates that the rocks are near a volcanic source. Thus lavas with island arc affinities were extruded within $90 \mathrm{~km}$ of the present trench axis. The geochemistry of these lavas is similar to that of an immature island arc or active margin, consistent with the apparent limited extent of these rocks (Fujioka and Nasu, 1978; Fujioka, this volume).

The presence of another igneous body near the trench slope break is indicated by the seismic refraction results reported by Nagumo and others (this volume). A refraction measurement made by ocean bottom seismograph (OBS) near the center of the filled channel in Record 2 (Figure 4) indicates a $6.0 \mathrm{~km} / \mathrm{s}$ layer at $2.35 \mathrm{~km}$ depth. The top of this high-velocity rock body is at the depth of the erosional unconformity below which rocks elsewhere on the deep sea terrace have velocities of 3.6 to $4.3 \mathrm{~km} / \mathrm{s}$ (Murauchi and Ludwig, this volume). An igne- 
ous body intruded into the Cretaceous sediment and truncated at the regional unconformity would fit these observations. A few low-amplitude magnetic anomalies in the Ishikari-Hidaka fore-arc basin also may indicate other occurrences of the volcanic rock (Murakami et al., 1977). Measurements show that the volcanic rocks from Sites 438 and 439 have a low magnetic susceptibility and sparse magnetic mineral content (Fujioka et al., this volume).

Pacific margin island arc volcanism usually produces igneous rock of intermediate composition. It is widely believed that the extrusive rocks are generated at depths of 100 to $150 \mathrm{~km}$, because belts of andesitic volcanism are typically found where the underlying Wadati-Benioff zone is 100 to $150 \mathrm{~km}$ deep. The lithosphere below Sites 438 and 439 is shallow (15-20 km deep) and the temperature at the depth of the lithosphere is low $\left(250^{\circ} \mathrm{C}-300^{\circ} \mathrm{C}\right.$.) Given such a low temperature, magma generation within the present subduction geometry seems unlikely. The implication is that at the time of dacitic magmatism, the Wadati-Benioff zone had a much greater depth and thus that the axis of the trench was farther from Sites 438 and 439 than at present. Otherwise the magma would have had to travel diagonally from the present area of generation, as suggested by Shiki (1978), which would add at least $50 \mathrm{~km}$ to its path and promote cooling.

During the period in which the hypabyssal and volcanic parent body for the conglomerate was cooling, certain other major tectonic events occurred. This was approximately the time of opening of the Sea of Japan, when the islands drifted away from the Asian mainland. It was also the time of intense submarine volcanism along the present magmatic arc that resulted in the lower Green Tuffs on Honshu and Hokkaido. It may also have been a time of unusual transition from the previous tectonic framework to the present magmatic arc and subduction zone.

\section{SUBSIDENCE OF THE DEEP SEA TERRACE}

The stratigraphy at Sites 438 and 439, combined with the seismic reflection records, indicate a history of sediment accumulation in the Cretaceous, landward tilting, and perhaps repetition of the section by tectonism between the Late Cretaceous and late Paleogene, followed by or partially coincident with uplift of a landmass erosion. This paleolandmass has been named Oyashio landmass-Oyashio Koriku in Japanese-(von Huene, Nasu, et al., 1978). Erosion cut the Oyashio landmass perhaps as deep as $2 \mathrm{~km}$ (if we can assume that secondary mineral assemblages reflect depth of formation rather than other factors, Iijima and others, this volume), and the upturned Cretaceous section was intruded by acidic and intermediate magma during the latest Oligocene. During erosion the area began to subside, perhaps in the late Paleogene; it was submerged at Sites 438 and 439 in latest Oligocene time, probably shortly after the magmatic episode had extruded volcanic products. The area continued to subside until the Pliocene, when it began to rise (Keller, this volume).

Van Hinte (1978) developed a way to diagram the history of subsidence and sediment accumulation which we have used in Figure 8 . The subaerial erosion surface at Sites 438 and 439 subsided below sea level at about 22 m.y.B.P. The rate of subsidence was above $250 \mathrm{~m} / \mathrm{m}$.y. through the early Miocene and sedimentation rates were relatively low $(30 \mathrm{~m} / \mathrm{m}$.y.) so that the seafloor had subsided to at least $1.5 \mathrm{~km}$ below sea level by the end of the early Miocene. Because sediment loading was negligible and the relative sea level rise during the late Oligocene and early Miocene, postulated by Vail and others (1977), is not of this magnitude, we infer that subsidence was tectonically controlled. Initial subsidence at Site 439 is unknown because the Oyashio ancient landmass has been eroded to a depth (approx. $2 \mathrm{~km}$ ) where chlorite minerals form, and thus it may have had considerable relief above sealevel. Because the unconformable surface landward of the sites is progressively onlapped by older strata, perhaps late Paleogene in age (Nasu and others, this volume), we conclude that subsidence in the area landward from Sites 438 and 439 probably began to subside sometime during the late Paleogene. Subsidence below sea level apparently first occurred on the west side of Oyashio landmass and progressed eastward.

In the JNOC and Shell Exploration Company multichannel seismic records, successively younger strata downlap against the unconformity as one progresses from the west end of the records to about the trench upper slope (Nasu et al., this volume). If downlap represents the first marine sedimentation as the sea transgressed over the subsiding Oyashio landmass, as it does near Sites 438 and 439, then Oyashio must have subsided steadily through the early Neogene. By the late Miocene, most of the landmass along JNOC Record 1 and perhaps all of it in JNOC Record 2 had subsided below sea level. Because the seaward (east) end of the unconformity is depressed about $3 \mathrm{~km}$ more than it is at Sites 438 and 439 , we conclude that the rate of subsidence in the late Miocene and Pliocene must have been greater along the eastern edge of the margin than along the present trench upper slope.

Interpretation of seismic records indicates a seaward shift of sediment depocenters, perhaps in response to more rapid subsidence of the seaward relative to the landward part of the margin (Arthur et al. and Nasu et al., this volume). The pre-middle Miocene depocenter is landward from Sites 438 and 439; the late Miocene depocenter is somewhat seaward of the sites; and the Pliocene depocenter has moved much farther seaward, well down the trench upper slope. From shift of the depocenter it also appears that in the Pliocene a great amount of subsidence occurred rapidly at the seaward edge of the margin, whereas subsidence diminished at the landward part of the deep sea terrace near Sites 438 and 439.

The extent of the Oyashio landmass at the beginning of the Neogene is only suggested by our data. Along JNOC Record 2 (Figure 4), the Oyashio landmass appears separated from Honshu because of the thick Paleogene sediment in a basin that extended from the west end of the record nearly to the Japan coast (Ishiwada and Ogawa, 1976). Thus the west shoreline of early Neogene Oyashio may have been approximately where the unconformity appears to lose angular discordance, at 


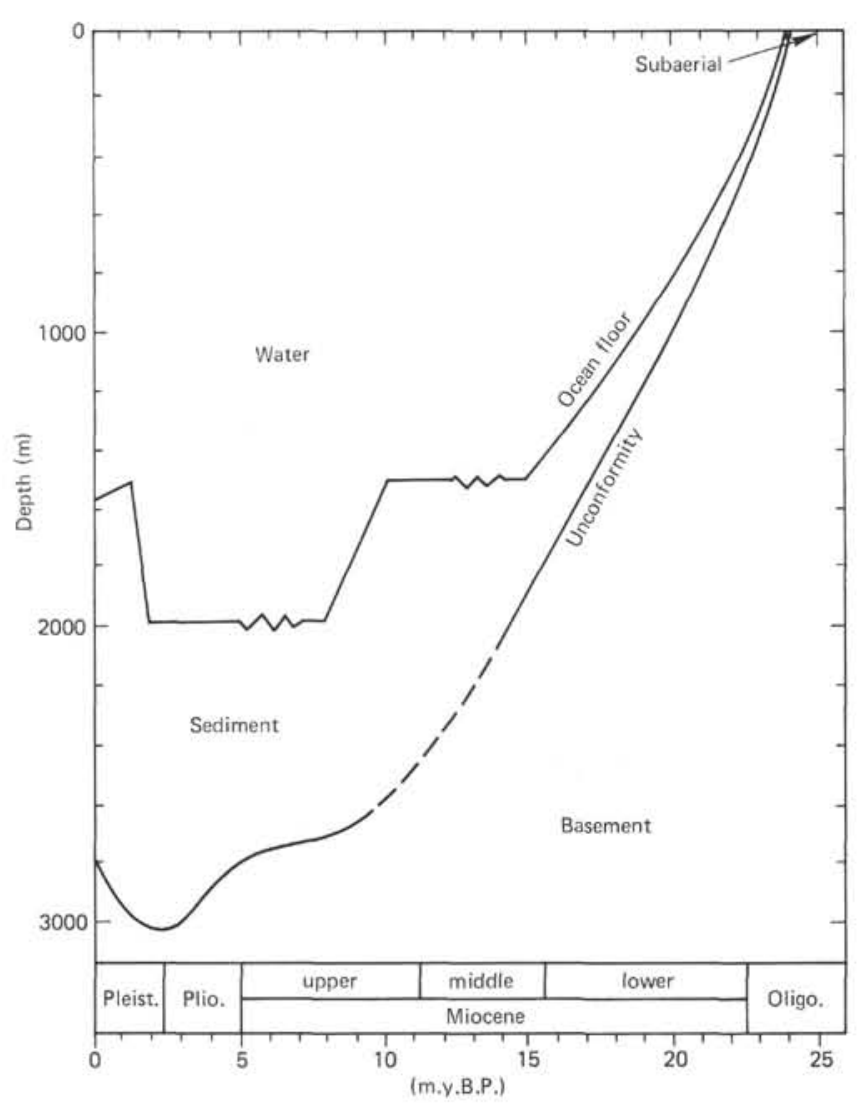

Figure 8. A diagram of sediment thickness above the unconformity and depth of depositional environments as a function of time for Sites 438 and 439. The illustration summarizes the subsidence of the Oyashio landmass with respect to sea level.

the west end of JNOC Record 2. The gradual subsidence of the west flank of the Oyashio landmass is seen in the progressively younger beds that downlap against the unconformity (Figure 4). This downlap shows the seaward transgression of the Ishikari-Hidaka fore-arc basin which ended when the last remnant of the Oyashio landmass had subsided, probably near the area of less angular discordance across the unconformity on the trench upper and midslope. Unfortunately, at this point the seismic records gradually lose resolution because of the greater depth of water and perhaps also because of structural complexity (Nasu et al., this volume). The remaining question is where the seaward coast was located. A transgression toward the last remnant of the Oyashio landmass from the seaward side is obscured in the JNOC records or missing altogether. The Shell Exploration Company record just south of JNOC Record 2 shows the landward downlap against the unconformity, which involves progressively younger beds in a direction toward land. Thus along JNOC Record 2 the last remnant of the Oyashio landmass that subsided in late Miocene time appears to have been a broad, low surface at the present trench upper slope. The seaward extent of the Oyashio landmass is unknown, but it appears to have been at least near the present midslope terrace and probably farther seaward (Figure 9). The more rapid rate of subsidence during the Pliocene may also have been simultaneous with the Pliocene event discussed earlier that caused a reshaping of the trench lower slope.

The subsidence of the Oyashio landmass indicates that the continent adjusted isostatically to the removal of material or to some other large increase in crustal density beneath its leading edge. Seismic data are insufficient to study the subsidence in three dimensions, but from two-dimensional examination, and assuming that the removal of material caused the Oyashio landmass to subside, the total volume of the continental framework decreased rather than increased during Neogene plate convergence. A minimum approximation of material loss can be made using JNOC Record 1 (Figure 4). In Record 1 the Oyashio landmass erosional surface appears to have been emergent at the beginning of the upper Miocene from shotpoint (SP) 800 , its landward end, for $60 \mathrm{~km}$ seaward to at least SP 2000 , at the midslope terrace, where the unconformity becomes obscured (Figure 4). The unconformity has subsided at least 3.1 $\mathrm{km}$ at SP 800 and $6.1 \mathrm{~km}$ at SP 2000 (Nasu et al., this volume). The cross-sectional area of the record between the unconformity and sea level is about $275 \mathrm{~km}^{2}$. By comparison, the area of sedimentary rock from SP 2000 , which is at the edge of the continental crust (Murauchi and Ludwig, this volume), to the trench is about $100 \mathrm{~km}^{2}$. Thus near JNOC Record 1, the subsiding upper Miocene remnant of the Oyashio landmass alone left a space more than twice as large as the maximum amount of sediment added to the continent by downslope mass movement, sedimentation, or subduction accretion during the same period of time; in short, a net decrease in continental volume has occurred during the time of subduction as inferred from associated arc volcanism and global plate tectonic reconstruction (Minister and Jordan, 1978).

\section{STRUCTURE OF THE LOWER SLOPE}

The trench lower slope is the closest morphotectonic element to the subduction zone where hundreds of kilometers of ocean crust are inferred to have been thrust beneath the continent in Neogene time. The evidence for subduction comes from global studies of magnetic anomalies, earthquake slip vectors hot-spot tracks, and transform faults (Minister and Jordan, 1978). Evidence for tectonic deformation at convergent margins commensurate with subduction of such large tracts of ocean crust is much less convincing, perhaps because geophysical techniques are unable to provide sufficient resolution of complex structure at the great ocean depths along trenches. In fact, these great depths also make sampling with the Glomar Challenger difficult, and sampling in the Japan Trench floor is beyond the Challenger's capability. Nonetheless, the combined geophysical and drill data from the Japan Trench transect constrain interpretations of trench lower slope structure much more than single-channel seismic reflection data, on which most simple models are based.

The refraction measurements indicate that near JNOC Record 2, crust with a continental velocity structure ends just seaward of the trench midslope terrace 

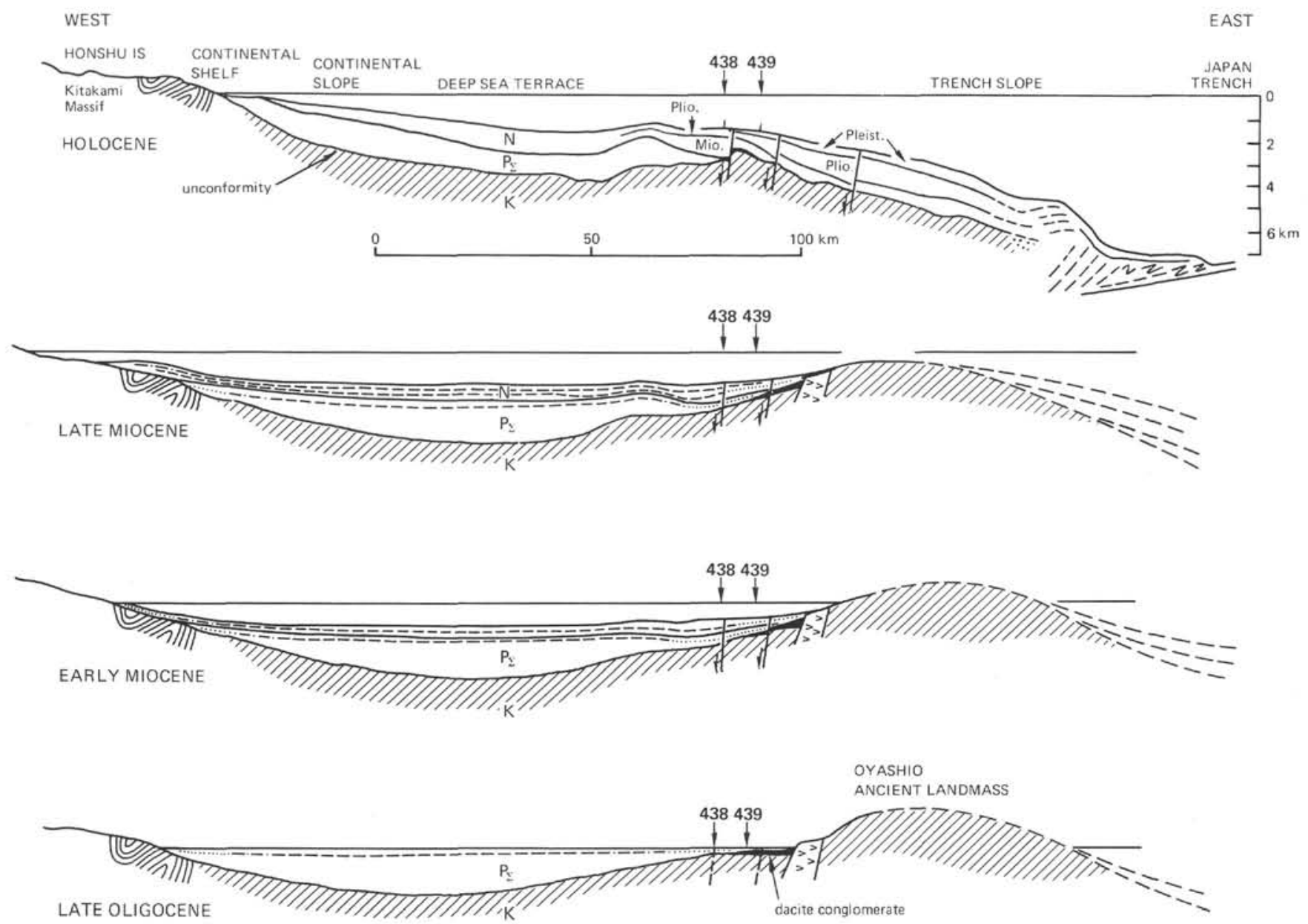

Figure 9. Diagrammatic history of the Oyashio landmass during subsidence with respect to sea level. $K=$ Cretaceous deposits; $P e=$ Paleogene deposits; $N=$ Neogene deposits. Areas of inferred structure are indicated by dashed lines.

and the trench lower slope has an oceanic structure overlain by low-velocity sediment $(V=1.6-3.1 \mathrm{~km} / \mathrm{s}$, Murauchi and Ludwig, this volume). The top of the igneous oceanic crust is one of the clearest reflective events beneath the lower slope in seismic reflection data (Nasu et al., this volume).

In the northernmost seismic-reflection record, JNOC Record 1, the lower slope consists of a broad midslope terrace, a steep slope, and an elongate toe, which is interpreted as a product of mass movement into the trench (Figure 10). Beneath the steep slope in Record 1, reflections are subhorizontal; near the igneous ocean crust some landward-dipping reflections may occur (Figures 4 and 10).

In ORI Records 78-3 and 78-4 (Nasu et al., this volume) a similar but smaller toe appears. Reflections in the thick low-velocity sediment body are again subhorizontal and perhaps dip landward just above the igneous ocean crust (Nasu et al., this volume). In ORI Record 78-4 the subhorizontal section looks particularly well organized and only slightly deformed. Thus, only the lower and most obscure part of the reflective sequences in these three records may have the landwarddipping structure associated with subduction-accretion complexes.
In JNOC Record 2, the southernmost of the multichannel records, the toe is no longer apparent (Figure 4). The upper sequence contains a few subhorizontal reflections and reflections paralleling the ocean floor. These reflections were drilled; they are slope deposits in a normal age sequence back to the late Miocene with a thin repeated interval in Hole 434B. The underlying section contains landward-dipping reflections and could be interpreted as a possible subduction-accretion complex. This is the largest possible subduction-accretion complex identified in any multichannel seismic record from the Japan Trench transect. If this complex was sampled at the bottom of Hole 434B, it is of late Miocene age (slightly more than $6 \mathrm{~m}$.y. old); if only the slope deposits were sampled, the subduction-accretion complex is late Miocene or older.

If we assume a minimum age of late Miocene for the subduction-accretion complex, it is possible to compare an estimate of the sediment arriving at the trench during this period with the sediment that was estimated to have been scraped off. Assuming a maximum cross-sectional area (maximum average sonic velocity $2.8 \mathrm{~km} / \mathrm{s}$ ) and maximum compaction (average water content $=20$ percent) the maximum sediment inferred to have been accreted is about 25 per cent of the sediment input assum- 

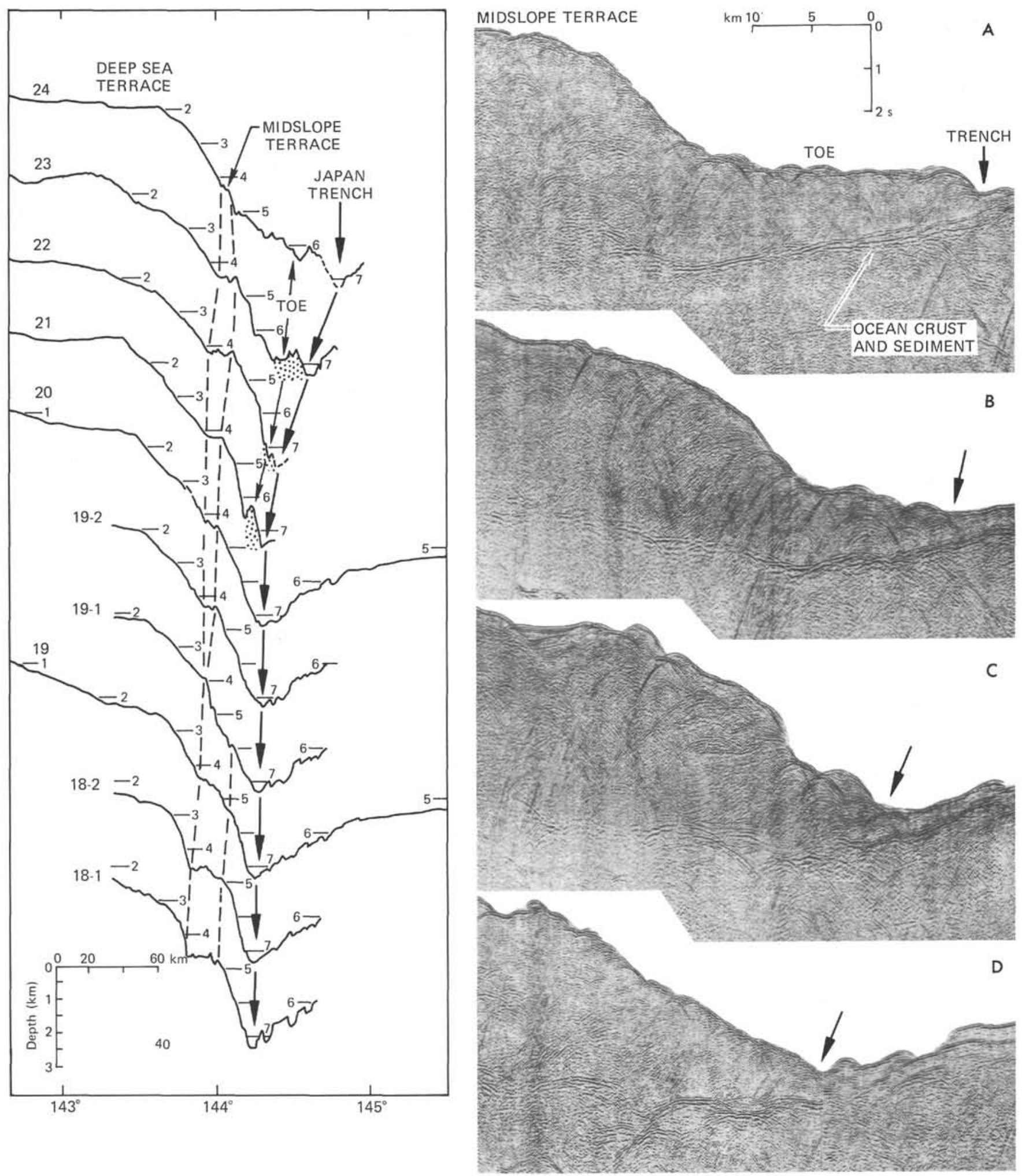

Figure 10. The Japan Trench lower slope as seen in 4 multichannel records. Records $A$ and $D$ are JNOC 1 and 2, respectively; Records $B$ and $C$ are ORI 78-3 and 78-4, respectively. Bathymetric profiles on the left are from Honza (this volume). Record A corresponds in position to 23, B to 22, C to 21, and Record D is between 19 and 19-1. 
ing $600-\mathrm{km}$ convergence in $6 \mathrm{~m} . \mathrm{y}$. and sediment 500 meters thick (thickness at Site 436) with 50 per cent water content. Thus despite the imprecision of the estimates, a large amount of sediment is being subducted if the present convergence rates have prevailed along the Japan Trench during the past 6 m.y.

Evidence for compressional deformation is not strong in the data from the trench lower slope; however, this may in part be a matter of resolution. Rock in the deepest core from sites on the middle and lower slope is intensely deformed (Sites 440, 441, and 434). Arthur and others (this volume) have developed an inferred sequence of deformation that begins with a microfracture fabric initally caused by dewatering structures that develop into a tectonic microbreccia with increasing depth of burial (Figure 11). During the dewatering process, impermeable sediment impedes the escape of interstitial water resulting in the development of water escape veins. As the sediment becomes more lithified and is able to transmit stress, the veins that are oriented in a preferential stress direction develop into fractures and microfaults. At depths between 200 and 600 meters, a zone of geopressured microfractured rock may form zones of low shear strength and thus may provide major slip planes for downslope mass movement. In the cores from Sites 440,441 , and 434 , both normal and reverse faults were found as well as evidence for mass movement. There is no evidence in the drill data for a dominance of compression, extension, or mass movement. However, deformation on the trench lower slope affects rocks at much shallower depths than it does rocks at the same depth in more static environments on the oceanic crust or on the deep sea terrace (Moore, this volume). Thus, evidence from the lower slope suggests that it is a zone of more intense tectonism and downslope mass movement than in adjacent areas, but the nature of the movement has not been determined convincingly.

Microfracturing may be one explanation of the low seismicity at the leading edge of subduction zones. Rather than fracturing along single widely spaced faults, the frontal part of a subduction zone may consist of a microbreccia, where creeplike deformation occurs on a multitude of small faults. This possibility is being tested in other presently active subduction zones by measurements of seismicity such as the Hawaii Institute of Geophysics experiment off Guatemala (von Huene et al., in press).

\section{A MODEL OF SUBDUCTION EROSION}

The results of DSDP drilling and the multichannel seismic work along the Japan Trench Transect provide new insights into the tectonic processes and evolution of the Japan convergent margir. As discussed earlier, the deep sea terrace east of northern Honshu is subsided landmass. The structure of the trench slope and the occurrence of middle Tertiary immature island arc magmatism at the trench slope break both suggest that the trench axis was once located farther east than at present and that during the Neogene the axis moved westward relative to Honshu.

One interpretation of this history is that the continental crust and lithosphere beneath are being actively eroded by the subduction process. In this last section, we shall discuss how the data support this interpretation and speculate on how such erosion may take place.

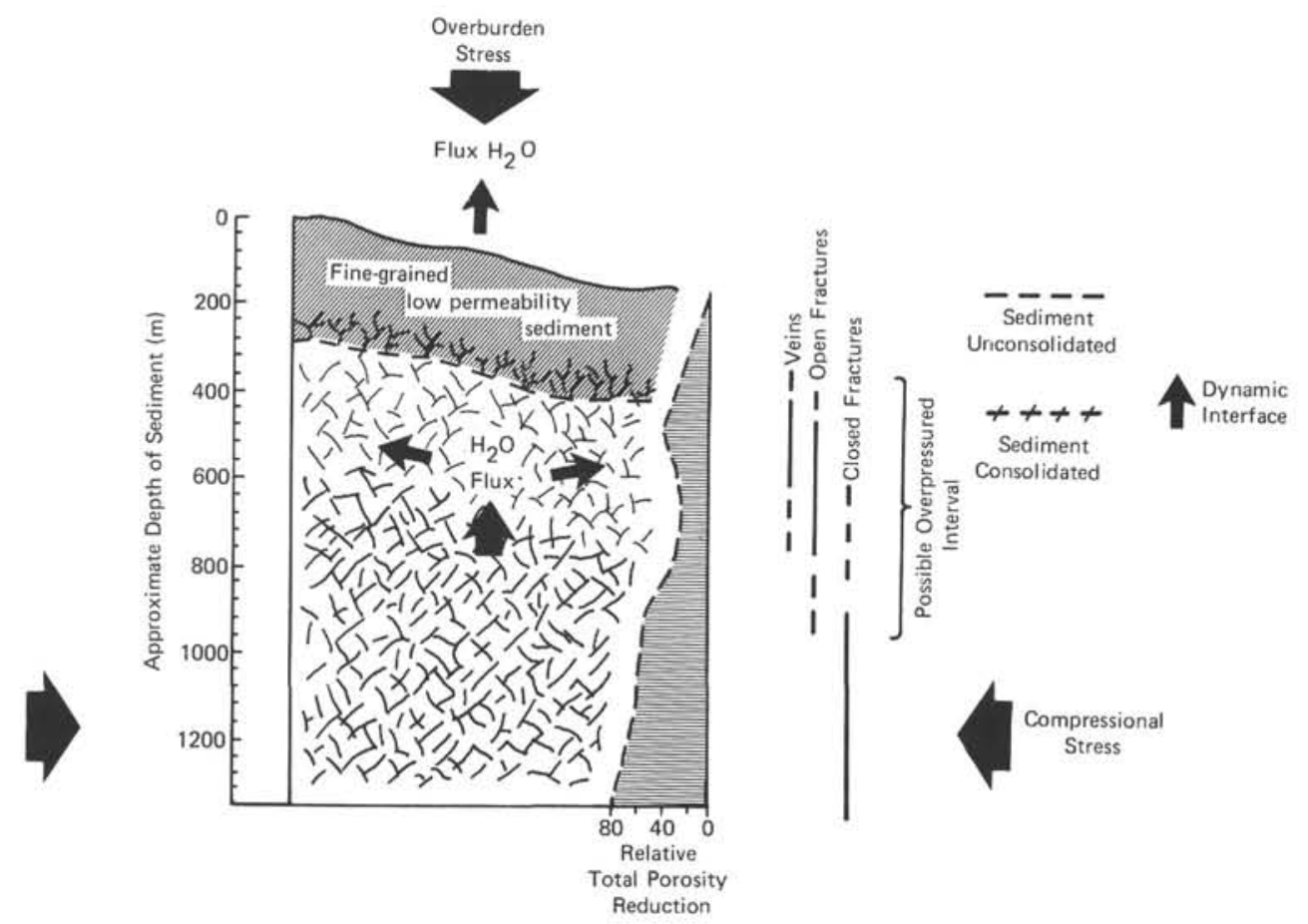

Figure 11. Schematic model of the response of fine-grained slope sediment to compaction on the Japan Trench lower slope. 
The model we will examine is a modification of one proposed by Murauchi (1971) for the Japan margin. He suggests that slices at the base of the overthrusting continental block may be sheared away and subducted with the oceanic lithosphere (see also the discussion in Murauchi and Ludwig, this volume). The process envisioned is one in which the plane of shearing moves upward into the overriding block (Figure 12) so that a lamina of continental material (the slice labeled 1 in Figure 12) is incorporated into the top of the subducting slab. Murauchi and Ludwig (this volume) suggest that water being carried down with the oceanic plate may be responsible for the upward shift of the plane of shearing. Upward migration of pore water squeezed from sediment and oceanic crust serves to reduce the shear strength of rocks riding above the shear plane (Arthur et al., this volume).

This removal of material from the base of the overriding block leads to thinning of the wedge and eventually to faulting of the seaward edge of the continental platform. As illustrated in Figure 12, the subduction of the basal slab (1) causes downward faulting of Block B. This leads to landward migration of the midslope terrace, which, by this model, is the surface expression of an advancing tectonic front. Block B and the deep sea terrace sediments lying on it become incorporated into the lower slope sedimentary mass, as was Block A at an earlier stage. It is possible that during the episode of subduction erosion significant amounts of sediment in the deeper part of the lower slope are also subducted. the consequent reduction in volume of the sedimentary mass leads to landward migration of the trench axis, as is suggested in Figure 12, Stage II.

We believe that this model explains the surprising discovery that sediments on the lower slope, about 1400

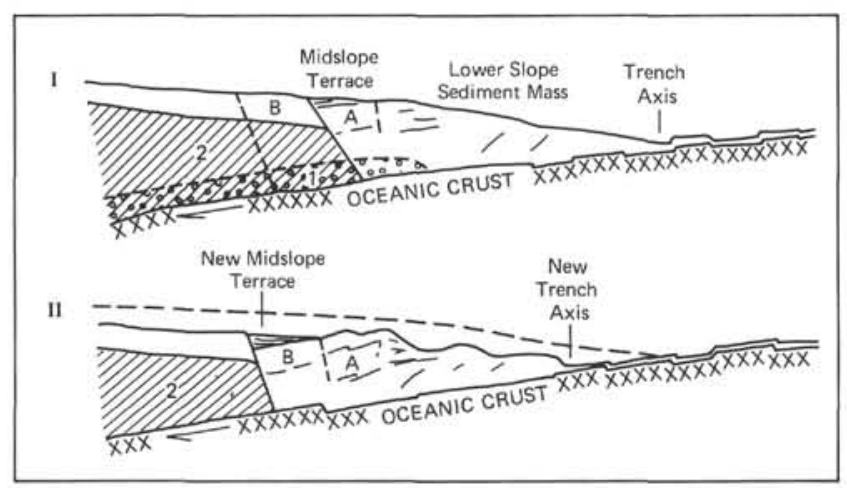

Figure 12. Schematic model of tectonic erosion by stoping at the base of the continental crust. In Stage I a slice of the continental crust (1) is incorporated into subducting oceanic lithosphere and carried down. Note that for purposes of illustration we have made the slice thick. It is more likely that it is in fact quite thin and that the erosion event occurs more frequently. This leads to Stage II, with thinning of the seaward edge of the continental crust, subsidence, collapse of the lower slope sedimentary mass, and landward migration of the trench axis and midslope terrace. meters above the trench floor, occurred in essentially normal age sequence back to the late Miocene and had accumulated at high rates. Possibly they are prograded sediments or sediment deposited on a former midslope terrace which faulted into the lower slope sedimentary complex as the midslope terrace migrated landward. Biostratigraphic and sedimentologic indicators imply that the sediments at Sites 434,441 , and 440 are truly slope sediments. According to this interpretation, the thin repeated sections indicated by the diatom stratigraphy (Harper, this volume) may have resulted from repeated slumps or flows into a Pliocene midslope terrace basin.

Another implication of the subduction erosional model and landward migration of the trench axis is that only a small proportion of the sediment in the lower slope sedimentary mass consists of accreted sediments. However, most of the sediment brought in on the oceanic lithosphere is rapidly subducted, so that over the long run the present Japan Trench margin is nonaccreting.

The model we have proposed suggests that trench migration and subduction-erosion of the continent occur episodically. If, as we assume, midslope terrace deposits are the thicker section of Pliocene sediments at Sites 441 and 434 , the interval between individual episodes of erosion is a few million years and the landward migration rate of the trench is several kilometers per million years. This rate is also consistent with the amount of subduction-accretion that can be accommodated beneath the present trench lower slope, which is equivalent to total accretion of ocean basin sediment over 2 to 3 million years at present convergence rates.

More examples of nonaccreting convergent margins have recently been found. Results from Leg 60, which drilled at the Mariana Arc and Trench complex (Hussong, Uyeda, et al., 1978), show that similar tectonics may occur there. Hussong et al. (1976), Kulm (1977), Shepherd (1979), and Coulbourn (in press) have noted that subduction-erosion may be occurring along certain sections of the Peru-Chile Trench. The staff of Leg 67 suggested that this mechanism may explain the results of drilling along the Mid-America Trench off Guatemala (von Huene et al., in press). Margins where the rates of convergence are large commonly seem to have small accretionary accumulations of sediment along the trench landward wall. Thus the processes deduced from drilling and geophysical work on the Japan Trench Transect may be more widespread than we realized up to now.

\section{REFERENCES}

Beck, R. H., Lehner, P., Diebold, P., Bakker, G., and Doust, H., 1976. New geophysical data on key problems of global tectonics. Proceedings of the 9th World Petroleum Congress, 2, 3-32.

Coulbourn, W., in press. Tectonics of the Nazca Plate edge and the continental margin of western South America, $18-23^{\circ} \mathrm{S}$ latitude. In Kulm, L. D., Hussong, D., Dymond, J., and Dash, J. (Eds.), The Nazca Plate and Adjacent Southern American Margin: Geol. Soc. Am. Bull. Mem.

Fujioka, K., and Nasu, N., 1978. Chemical composition of the volcanic rocks from the Oyashio Ancient Landmass. 
American Geophysical Union, EOS, 59 (No. 12), 11831184. (Abstract)

Honza, E. (Ed.), 1977. Geological investigation of Japan and southern Kurile Trench and slope areas, GH 76-2 cruise April-June, 1976. Geological Survey of Japan Cruise Report No. 7.

Hunahashi, M., 1957. Alpine orogenic movement in Hokkaido, Japan. J. Fac. Sci., Hokkaido Imp. Univ. 9, 415-496. (in Japanese with English abstract)

Hussong, D. M., Edwards, P. B., Johnson, S. H., Campbell, J. R., and Sutton, G. H., 1976. Crustal structure of the Peru-Chile Trench; $8-12^{\circ} \mathrm{S}$ latitude. In Sutton, G. H., Manghnani, M. H., Moberly, R., and McAfee, E. U. (Eds.), The Geophysics of the Pacific Ocean Basin and Its Margin: Geophysical Monograph 19: Washington (American Geophysical Union), pp. 17-85.

Hussong, D., Uyeda, S., Blanchet, R., Bleil, V., Ellis, C. H., Francis, T. T. G., Fryer, P., Horai, K., Kling, S., Meijer, A., Nakamura, K., Natland, J., Packham, G., and Sharaskin, A., 1978. Leg 60 ends in Guam. Geotimes, 23, 19-22.

Inouchi, Y., Yuasa, M., and Onodera, K., 1976. Cored materials. In Honza, E. (Ed.), Geological Investigation of Japan and Southern Kurile Trench and Slope Areas: GH 76-2 Cruise April-June 1976: Tsukuba (Geological Survey of Japan).

Ishiwada, Y., and Ogawa, K., 1976. Petroleum geology of offshore areas around the Japanese Islands. UN-ESCAP, CCOP Tech. Bull., 10, 23-34.

Kulm, L. D., Schweller, W. J., and Maias, A., 1977. A preliminary analysis of the subduction processes along the Andian continental margin, $6^{\circ}$ to $45^{\circ} \mathrm{S}$. In Talwani, M., and Pitman III, W. C. (Eds.), Island Arcs, Deep Sea Trenches and Back-Arc Basins: Washington (American Geophysical Union), pp. 285-302.

Ludwig, W. J., Ewing, J. I., Ewing, M., Murauchi, S., Den, N., Asano, S., Hotta, H., Hayakawa, M., Asanuma, T., Ichikawa, K., and Noguchi, I., 1966. Sediments and structure of the Japan Trench. J. Geophys. Res., 71, 2121-2137.

Minear, J. W., and Toksø̋z, M. N., 1970. Thermal regime of a downgoing slab and new global tectonics. J. Geophys. Res., 75, 1397-1419.

Minister, J. B., and Jordan, T. H., 1978. Present day plate motions. J. Geophys. Res., 83, 5331-5354.

Murakami, F., Tamaki, K., and Nishimura, K., 1977. Geomagnetic survey. In Honza, E. (Ed.), Geological Investiga- tion of Japan and Southern Kurile Trench and Slope Areas: GH 76-2 Cruise April-June 1976: Tokyo (Geological Survey of Japan), pp. 43-49.

Murauchi, S., 1971. The renewal of island arcs and the tectonics of marginal seas. Island Arc and Marginal Sea: Tokyo (Tokai University Press), pp. 39-56. (in Japanese with English abstract)

Nagao, T., 1938. Tertiary orogeny in Hokkaido. J. Fac. Sci. Hokkaido Imp. Univ., Ser. 4, 4, 23-30.

Nasu, N., 1964. The provenance of the coarse sediments on the continental shelves and the trench slopes off the Japanese Pacific coast. In Miller, R. L. (Ed.), Papers in Marine Geology: New York (Macmillan), pp. 65-101.

Okada, H., 1974. Migration of ancient arc-trench systems. In Dott, R. H., and Shaver, R. H. (Eds.), Modern and Ancient Geosynclinal Sedimentation: Soc. Econ. Paleont. Mineral., Spec. Pub. No. 19, pp. 311-320.

, in press. Sedimentary patterns in apparent back-arc basins: A case study of the Neogene sequence in northwestern Hokkaido, Japan. J. Geophys. Earth.

Oxburgh, E. R., and Turcotte, D. L., 1970. Thermal structure of island arcs. Geol. Soc. Am. Bull., 81, 1665-1688.

Shepherd, G. L., 1979. Shallow crustal structure and marine geology of a convergence zone, northwest Peru and southwest Ecuador [Ph.D. dissert.]. University of Hawaii.

Shiki, T., 1978. Structure and tectonics under the continental slopes of the Honshu Arc. American Geophysical Union, 1978 Fall annual meeting EOS, 59 (No. 12), 1183. (Abstract)

Vail, P. R., Mitchum, R. M., and Thompson III, S., 1977. Global cycles to relative changes of sea level. Seismic stratigraphy - Application to Hydrocarbon Exploration, Memoir 26: Am. Assoc. Pet. Geol., pp. 83-98.

van Hinte, J. E., 1978. Geohistory analysis - application of micropaleontology in exploration geology. Am. Assoc. Pet. Geol. Bull., 62 (No. 2), 201-222.

von Huene, R., Aubouin, J., Azema, J., Blackinton, G., Carter, J., Coulbourn, W., Cowan, D., Curiale, J., Dengo, C., Faas, R., Harrison, W., Hesse, R., Hussong, D., Ladd, J., Muzlov, N., Shiki, T., Thompson, P., and Westberg, $\mathrm{J}$. , in press. The IPOD Mid-America Trench transect off Guatemala. Geol. Soc. Bull.

von Huene, R., Nasu, N., Arthur, M., Cadet, J. P., Carson, B., Moore, G. W., Honza, E., Fujioka, K., Barron, J. A., Keller, G., Reynolds, R., Shaffer, B. L., Sato, S., and Bell, G., 1978. On Leg 57, Japan Trench transected. Geotimes, April, 1978, pp. 16-21. 